\title{
Specific IgG and IgA Antibody Reactivities in Sera of Children by Enzyme-Linked Immunoassay and Comparison With Giardia duodenalis Diagnosis in Feces
}

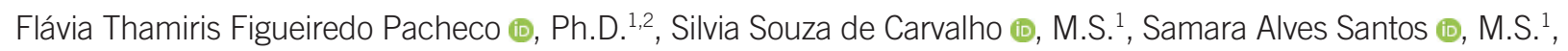
Gisele Maria Trindade das Chagas (ㅁ, B.Pharm. ${ }^{1}$, Mariana Conceição Santos 투, B.Pharm. ${ }^{1}$, Jéssica Gleide Souza Santos (i), B.Pharm. ${ }^{1}$, Hugo da Costa-Ribeiro Júnior (10, Ph.D. ${ }^{2}$, Tereza Cristina Medrado Ribeiro (i), Ph.D. ${ }^{2}$, Ângela Peixoto de Mattos (i),

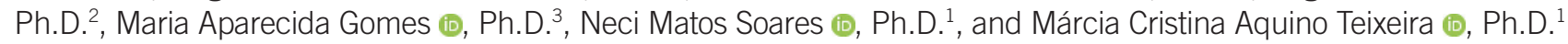

${ }^{1}$ Department of Clinical and Toxicological Analysis, Pharmacy College and ${ }^{2}$ Hospital Professor Edgard Santos, Federal University of Bahia, Salvador, Brazil; ${ }^{3}$ Department of Parasitology, Institute of Biological Sciences, Federal University of Minas Gerais, Belo Horizonte, Brazil

Background: Giardia duodenalis is conventionally diagnosed in fecal samples using parasitological methods. However, sensitivity is poor when only a single sample is analyzed, due to intermittent excretion of cysts in feces. Alternatively, the serum antibodies to $G$. duodenalis can be used for parasite diagnosis and epidemiological studies to determine previous exposure. We compared the rate of $G$. duodenalis infection between serum antiGiardia IgG and IgA antibodies and fecal examination in Brazilian children.

Methods: Fecal and serum samples were tested from 287 children at a clinical laboratory and from 187 children at daycare centers. Fecal samples were processed using conventional parasitological methods and coproantigen detection for Giardia diagnosis. Serum samples were tested using an in-house ELISA for detection of anti-Giardia IgG and IgA.

Results: $G$. duodenalis was found in $8.2 \%(N=39)$ of the 474 children analyzed. The sensitivity and specificity of ELISA were $80.0 \%$ and $90.0 \%$ for $\operatorname{lgG}$ and $80.0 \%$ and $83.3 \%$ for IgA, respectively. The total positivity rate of anti-Giardia IgG and IgA in the sera was $13.9 \%(N=66)$ and $23.6 \%(N=112)$. The agreement between the positivity of specific antibodies and the detection of $\mathrm{G}$. duodenalis in feces was moderate for ELISA-IgG, kappa index $(95 \% \mathrm{Cl})=0.543(0.422-0.664)$, and mild for ELISA-IgA, kappa index (95\% $\mathrm{Cl})=0.283(0.162-0.404)$. Among the children infected with other enteroparasites, $11.6 \%(\mathrm{~N}=10)$ and $24.4 \%(\mathrm{~N}=21)$ showed reactivity to anti-Giardia IgG and to IgA, respectively. This cross-reactivity was more frequent in samples from children infected with Endolimax nana and Entamoeba coli.

Conclusions: The higher frequency of specific antibody reactivity compared with G. duodenalis diagnosis in feces could reflect continuous exposure of children to $G$. duodenalis infection, resulting in long-lasting immunological memory and/or cross-reactivity with other intestinal amoebas.

Key Words: Giardia duodenalis, Infection, Children, Diagnosis, Antibodies, ELISA, CrossReactivity
Received: September 15, 2019

Revision received: January 5, 2020

Accepted: March 31, 2020

\section{Corresponding author:}

Márcia Cristina Aquino Teixeira, Ph.D. Department of Clinical and Toxicological Analysis, Pharmacy College, Federal University of Bahia, Salvador, Bahia 40170115, Brazil

Tel: +55-71-3283-6954

Fax: +55-71-3283-6949

E-mail:marciat@ufba.br

\section{(c) (i) (8)}

(๖) Korean Society for Laboratory Medicine This is an Open Access article distributed under the terms of the Creative Commons Attribution Non-Commercial License (https://creativecommons.org/licenses/by-nc/4.0) which permits unrestricted non-commercial use, distribution, and reproduction in any medium, provided the original work is properly cited. 


\section{INTRODUCTION}

Parasitic infections can cause anemia, malnutrition, and other impairments in physical and cognitive development, especially in children [1, 2]. Giardia duodenalis is one of the main etiological agents of diarrhea worldwide, accounting for approximately 28.2 million cases of diarrhea each year due to food contamination [3]. Protozoa transmission is considered a public health problem in developing countries, and since 2004, Giardia has been included in the WHO's "Neglected Diseases Initiative" group [4].

G. duodenalis infection shows a broad clinical spectrum, ranging from asymptomatic cases to acute or chronic diarrhea, abdominal pain, nausea and vomiting, dehydration, and weight loss [5, 6]. Children, especially those that attend childcare centers, are considered a high-risk group for $G$. duodenalis infection and its consequences, including impairment in physical and cognitive development $[5,6]$. The laboratory diagnosis of $G$. duodenalis is conventionally performed by microscopic identification of cysts and/or trophozoites in feces [7]. However, microscopic identification has limited sensitivity due to the intermittent elimination of $G$. duodenalis cysts in feces and requires trained technicians for accurate diagnosis $[4,5]$. Coproantigen tests based on ELISA or immunochromatography were also developed for detecting parasite proteins in feces and are considered more sensitive than microscopy-based methods [8-11]. In addition, the detection of antibodies against $G$. duodenalis in sera by ELISA or immunofluorescence can also be useful for diagnosis and seroepidemiological studies in large communities [12, 13]. High levels of specific antibodies against Giardia have been detected in populations from Mexico [12], the Caribbean [13], the United States [14], and Venezuela [15]. Although the detection of specific serum IgG antibodies cannot distinguish past from current infections, this approach nevertheless provides information on the overall exposure of a population. Studies suggest that the presence of serum or salivary anti-Giardia IgA indicates recent infections by $G$. duodenalis $[15,16]$. However, the results are controversial, and some reports have shown that neither IgA nor IgG can differentiate between past and current infection $[17,18]$. These debatable reports indicate the need for more studies to assess the efficacy of serology in $G$. duodenalis diagnosis as well to investigate its performance in pediatric population from endemic areas for intestinal parasitic infections. Commercially produced ELISA kits are not promptly available for detecting serum antibodies to Giardia infection. Therefore, the main objective of this study was to compare the diagnostic potential of an in house-ELISA for detecting specific antibodies in sera with the current G. duodenalis infection determined by microscopy and/or the presence of parasite antigens in the feces of children from Salvador, Bahia, Brazil.

\section{MATERIALS AND METHODS}

\section{Study design and population}

This cross-sectional study was conducted on children undergoing routine laboratory examinations at the Clinical Analysis Laboratory of Pharmacy College of the Federal University of Bahia $(\mathrm{N}=287)$ and those attending daycare centers $(\mathrm{N}=187)$ located in the same city district of Salvador, Bahia, Brazil. Overall, the children's ages ranged from 0-14 years, with those from daycares mostly $2-7$ years old.

The Ethics Committee of Nursing School, Federal University of Bahia, Brazil, approved the study (project approval No. 907.867). Children whose parents agreed to participate in the study and signed an informed consent form were enrolled during the study period. Children over eight years old were informed about the research and they signed a consent form. All parasitological tests results were sent to the children's parents.

The children were selected by convenience sampling from January 2015 to January 2016. Fecal and serum samples were collected from all participating children. At least two fecal samples were submitted for the diagnosis of $G$. duodenalis. Part of the feces was used for the parasitological examination, and the other was frozen at $-20^{\circ} \mathrm{C}$ for up to six months before testing for Giardia coproantigen. Tubes containing polymer gel for serum separation were centrifuged for 10 minutes at $1,620 \times g$, and sera were frozen at $-20^{\circ} \mathrm{C}$ until use. Standardization of the inhouse ELISA and study of seroprevalence of anti-Giardia IgG and IgA in children sera were performed in 2017.

\section{Diagnosis of intestinal parasites in fecal samples}

Stool samples were subjected to the following parasitological tests: (a) sedimentation by centrifugation in water [19]; (b) zinc sulfate (density of solution $1.18 \mathrm{~g} / \mathrm{mL}$ ) centrifugal flotation [20]; and (c) modified Ziehl-Neelsen staining [21]. Two slides were examined for each test. In addition to these parasitological tests, an ELISA kit (RIDASCREEN ${ }^{\circledR}$ Giardia, R-Biopharm AG, Germany) was used for detecting the Giardia coproantigens.

\section{In-house ELISA for detection of anti-Giardia $\lg G$ and $\lg A$}

$G$. duodenalis soluble antigen preparation

G. duodenalis trophozoites (strain WB) were axenically cultured in TYI-S-33 medium supplemented with serum and bovine bile 
(Keister's Modified TYIS33 Giardia Medium - ATCC Medium 2695; Virginia, USA), according to the procedure described by Keister [22]. The trophozoites were washed three times at $4^{\circ} \mathrm{C}$, $720 \times g$ for 10 minutes in sterile phosphate-buffered saline (PBS), pH 7.2. The suspension was then sonicated in an ice bath (15 cycles of 60 seconds at $90 \mathrm{~Hz}$ ). Protease inhibitors [0.05 mmol/L EDTA, $1 \mathrm{mmol} / \mathrm{L}$ phenylmethanesulfonyl fluoride, $0.05 \mathrm{mmol} / \mathrm{L}$ tosyl-L-phenylalanine chloromethyl ketone/tosyl-Llysine chloromethyl ketone, and $1 \mathrm{\mu g} / \mathrm{mL}$ leupeptin] were added to the antigen extract and centrifuged at 4,500 $\times \mathrm{g}$ for $30 \mathrm{~min}$ utes at $4^{\circ} \mathrm{C}$. The supernatant with soluble antigen was analyzed for protein content according to the method of Lowry, et al. [23], divided into aliquots, and stored at $-20^{\circ} \mathrm{C}$ until use.

\section{Standardization of in-house ELISA}

The indirect ELISA was standardized using 94 serum samples obtained from $30 \mathrm{G}$. duodenalis monoinfected children, 30 nonparasitized children, and 34 children who were infected with other intestinal parasites, including Endolimax nana, Entamoeba coli, Iodamoeba butschilli, Blastocystis hominis, Trichuris trichiura, Ascaris lumbricoides, Enterobius vermicularis, and Strongyloides stercoralis. These sera were different from the main samples tested to determine the seroprevalence of anti-Giardia IgG and IgA in children, and previously selected from children who routinely attended at the Clinical Analysis Laboratory of Pharmacy College, Federal University of Bahia. All fecal samples were examined at the Parasitology Laboratory as described in the previous section "Diagnosis of intestinal parasites in fecal samples" and, according to their parasitological results, they were chosen to integrate the set of control sera. G. duodenalisnegative samples were selected by parasitological examination of three fecal samples and by a coproantigen test, as mentioned above.

\section{ELISA for anti-Giardia IgG and IgA detection}

Microplate wells (Corning Costar polystyrene EIA/RIA plates, Corning) were coated with $20 \mu \mathrm{g} / \mathrm{mL}$ of $\mathrm{G}$. duodenalis antigen in $0.06 \mathrm{~mol} / \mathrm{L}$ carbonate-bicarbonate buffer $(\mathrm{pH}$ 9.6), incubated overnight at $4^{\circ} \mathrm{C}$, and washed three times with PBS containing $0.05 \%$ Tween-20 (PBS-T). The plates were blocked with $200 \mu \mathrm{L}$ of PBS-T containing 5\% w/v skim milk (PBS-T-milk) for 1 hour at $37^{\circ} \mathrm{C}$. After blocking, the wells were washed five times with PBS-T, filled with $100 \mu \mathrm{L}$ of serum samples diluted at $1 / 100$ (IgG) or 1/25 (IgA) diluted in PBS-T-milk, and incubated in duplicate for 1 hour at room temperature (RT; $27^{\circ} \mathrm{C}$ ). After another washing step, $100 \mu \mathrm{L}$ of horseradish peroxidase-conjugated anti-hu- man IgG (Sigma-Aldrich, St. Louis, MO, USA) or IgA (Thermo Fisher Scientific) antibodies diluted 1/1,000 in PBS-T-milk were added, followed by 1 -hour incubation at $37^{\circ} \mathrm{C}$. The plates were washed three times with PBS-T and twice with pure PBS. The reaction was visualized by adding $100 \mu \mathrm{L}$ of substrate $(0.051$ $\mathrm{mol} / \mathrm{L}$ citrate-phosphate buffer, $\mathrm{pH}$ 5.0, containing $0.004 \mathrm{~mol} / \mathrm{L}$ p-phenylenediamine and $0.040 \%$ hydrogen peroxide), and the plate was incubated for 20 minutes in the dark at RT. Twenty microliters of $8 \mathrm{~N}$ sulfuric acid was added to stop the reaction, and the optical density (OD) was measured at 450-630 nm with a microplate reader (Awareness Technology, Palm City, FL, USA). The antibody levels were expressed as the ELISA index (EI), calculated as the ratio between the OD of each tested sam-

Table 1. Characteristics of children and frequency of parasite infection

\begin{tabular}{lccc}
\hline & \multicolumn{3}{c}{ Children N (\%) } \\
\cline { 2 - 4 } & $\begin{array}{c}\text { Clinical } \\
\text { laboratory }\end{array}$ & $\begin{array}{c}\text { Daycare } \\
\text { centers }\end{array}$ & Total \\
\hline $\begin{array}{c}\text { Demographic characteristics } \\
\text { and parasitic infection }\end{array}$ & $287(60.6)$ & $187(39.4)$ & $474(100.0)$ \\
\hline
\end{tabular}

Sex

$\begin{array}{llll}\text { Female } & 128(44.6) & 96(51.3) & 224(47.3) \\ \text { Male } & 159(55.4) & 91(48.7) & 250(52.7)\end{array}$

Age range (yr)

$\begin{array}{lrrr}0-1 & 9(3.1) & - & 9(1.9) \\ 2-5 & 70(24.4) & 144(77.0) & 214(45.1) \\ 6-10 & 110(38.3) & 43(23.0) & 153(32.3) \\ 11-14 & 98(34.1) & - & 98(20.7)\end{array}$

Parasitism

$\begin{array}{lccc}\text { Monoparasitism } & 58(20.2) & 35(18.7) & 93(19.6) \\ \text { Biparasitism } & 19(6.6) & 3(1.6) & 22(4.6) \\ \text { Polyparasitism } & 3(1.0) & 5(2.7) & 8(1.7) \\ \text { Enteroparasites } & 80(27.9) & 43(23.0) & 123(25.9) \\ \text { Protozoa } & & & \\ \quad \text { Giardia duodenalis } & 23(8.0) & 16(8.6) & 39(8.2) \\ \text { Endolimax nana } & 36(12.5) & 20(10.7) & 56(11.8) \\ \text { Entamoeba coli } & 24(8.4) & 11(5.9) & 35(7.4) \\ \text { lodamoeba butschilli } & 5(1.7) & 2(1.1) & 7(1.5) \\ \text { Blastocystis hominis } & 2(0.7) & 9(4.8) & 11(2.3) \\ \text { Helminths } & & & \\ \text { Ascaris lumbricoides } & 6(2.1) & 3(1.6) & 9(1.9) \\ \text { Trichuris trichiura } & 8(2.8) & 0(0.0) & 8(1.7) \\ \text { Strongyloides stercoralis } & 1(0.3) & 0(0.0) & 1(0.2) \\ \text { Enterobius vermicularis } & 2(0.7) & 1(0.5) & 3(0.6)\end{array}$


ple and that at the cut-off point; samples with an El $>1$ were considered positive.

\section{Statistical analysis}

The data were analyzed using SPSS Statistics for Windows version 19 (IBM Corp., Armonk, NY, USA), and statistical analyses were performed with GraphPad Prism 7 (GraphPad Software, Inc., San Diego, CA, USA). The ELISA OD cut-off, sensitivity and specificity values were determined by the receiver operating characteristic (ROC) curve. The agreement between ELISA and a parasitological diagnosis of $G$. duodenalis infection was assessed with the kappa index [24]. Analysis of variance followed by Dunn's test was used to compare El values among groups (infected with G. duodenalis, infected with other protozoa or helminths, and non-infected children). $P<0.05$ was considered statistically significant.

\section{RESULTS}

Characterization of the population and frequency of enteroparasites

There was no significant difference among the children groups in relation to gender. Overall, $77.4 \%$ of children fell within the 2-10 years range; children under 2 years and $11-14$ years of age were all from the group examined at the clinical laboratory (Table 1). There was a predominance of monoparasitism by protozoa, and G. duodenalis was the most predominant pathogenic parasite found ( $8.2 \% ; \mathrm{N}=39$; Table 1$)$.

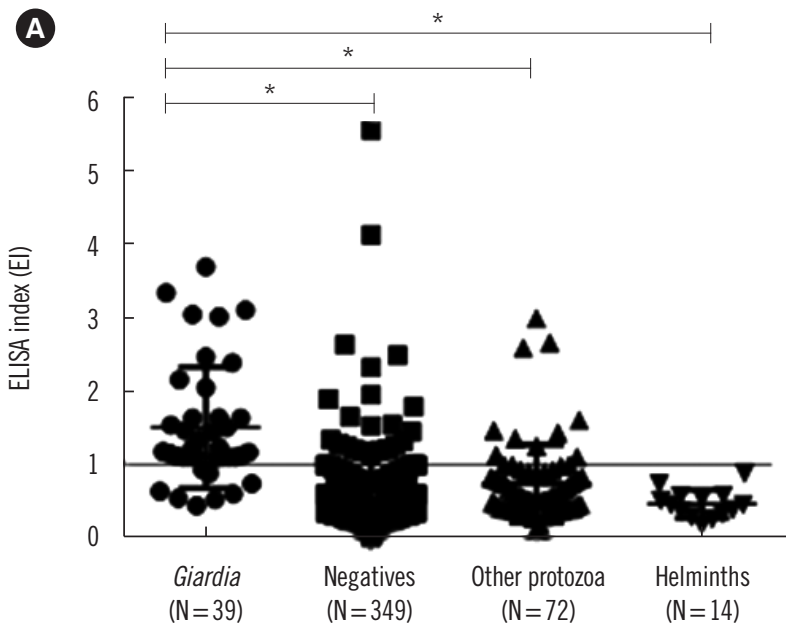

Detection of anti-Giardia $\lg \mathrm{G}$ and $\lg \mathrm{A}$ in sera

The sensitivity and specificity of ELISA were $80 \%$ and $90 \%$ for anti-Giardia IgG and 80\% and 83.3\% for IgA, respectively (Table 2). The OD cut-off value was 0.136 for IgG and 0.068 for IgA, which were used to calculate the Giardia antibody positivity rates in the study population.

The antibody reactivities were significantly higher in children infected with $G$. duodenalis $(P<0.001)$ compared with those of the other groups (Fig. 1). The seropositivity for anti-Giardia IgG and $\lg A$ was $13.9 \%(\mathrm{~N}=66)$ and $23.6 \%(\mathrm{~N}=112)$, respectively (Table 3). Of the 39 children who had G. duodenalis in feces, $79.5 \%(\mathrm{~N}=31)$ and $71.8 \%(\mathrm{~N}=28)$ showed seropositivity for IgG and IgA, respectively.

The agreement between the positivity rate of specific antibodies and the detection of $G$. duodenalis in feces was moderate for ELISA-IgG (kappa index [95\% Cl] =0.543 [0.422-0.664]) and mild for ELISA-lgA (kappa index [95\% Cl] $=0.283$ [0.1620.404]) (Table 4). Of the 86 children infected with other entero-

Table 2. Sensitivity, specificity, and cut-off value of the in-house ELISA for detection of anti-Giardia IgG and IgA antibodies in sera

\begin{tabular}{lccc}
\hline ELISA $^{*}$ & $\begin{array}{c}\text { Optical density } \\
\text { cut-off value }\end{array}$ & $\begin{array}{c}\text { Sensitivity } \\
(95 \% \mathrm{Cl})\end{array}$ & $\begin{array}{c}\text { Specificity } \\
(95 \% \mathrm{CI})\end{array}$ \\
\hline $\operatorname{lgG}$ & 0.136 & $80.0 \%(61.4-92.3 \%)$ & $90.0 \%(73.5-97.9 \%)$ \\
$\lg \mathrm{B}$ & 0.068 & $80.0 \%(78.9-89.2 \%)$ & $83.3 \%(51.6-89.8 \%)$
\end{tabular}

*The indirect ELISA was standardized using serum samples obtained from 30 G. duodenalis monoinfected children, 30 non-parasitized children, and 34 children infected with other intestinal parasites.

Abbreviation: $\mathrm{Cl}$, confidence interval.

B

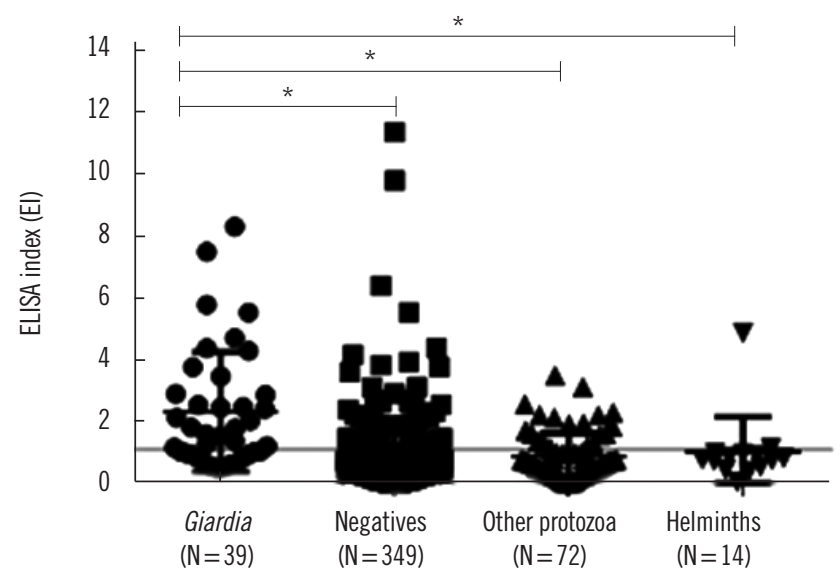

Fig. 1. Reactivities of anti-Giardia antibodies in sera of children according to their parasitological results. IgG (A) and IgA (B) levels of antiGiardia in serum samples are expressed as the ELISA index (EI). Symbols represent G. duodenalis-infected children ( $\bullet$ ), negatives ( $\mathbf{\square})$, and children infected with other protozoa $(\boldsymbol{\Delta})$ or helminths $(\boldsymbol{\nabla})$.

${ }^{*} P<0.001$ (ANOVA, Dunn test). 
Table 3. Seropositivity of anti-Giardia IgG and IgA in children, according to the presence of parasitic infection

\begin{tabular}{|c|c|c|c|c|c|c|c|c|c|c|}
\hline \multirow{3}{*}{\multicolumn{2}{|c|}{ Groups }} & \multicolumn{9}{|c|}{$\begin{array}{l}\text { ELISA positivity for anti-G. duodenalis antibodies } \\
\text { Total positives N/tested N (\%) }\end{array}$} \\
\hline & & \multicolumn{5}{|c|}{$\lg G$} & \multicolumn{4}{|c|}{ IgA } \\
\hline & & \multicolumn{2}{|c|}{$\begin{array}{l}\text { Clinical laboratory } \\
36 / 287(12.5)\end{array}$} & \multicolumn{2}{|c|}{$\begin{array}{l}\text { Daycare centers } \\
30 / 187(16.0)\end{array}$} & $\begin{array}{c}\text { Total } \\
66 / 474(13.9)\end{array}$ & \multicolumn{2}{|c|}{$\begin{array}{l}\text { Clinical laboratory } \\
58 / 287(20.2)\end{array}$} & $\begin{array}{l}\text { Daycare centers } \\
54 / 187(28.9)\end{array}$ & $\begin{array}{c}\text { Total } \\
112 / 474(23.6)\end{array}$ \\
\hline \multicolumn{2}{|c|}{ Children with $G$. duodenalis } & \multicolumn{2}{|c|}{$18 / 23(78.3)^{\dagger}$} & \multicolumn{2}{|c|}{$13 / 16(81.3)^{\ddagger}$} & $31 / 39(79.5)^{*}$ & \multicolumn{2}{|c|}{$17 / 23(73.9)^{\S}$} & $11 / 16(68.8)^{\|}$ & $28 / 39(71.8)^{*}$ \\
\hline \multicolumn{2}{|c|}{ Children with other protozoa } & \multicolumn{2}{|c|}{$6 / 46(13.0)^{\dagger}$} & \multicolumn{2}{|c|}{$4 / 26(15.4)^{\ddagger}$} & 10/72 (13.9) & \multicolumn{2}{|c|}{$10 / 46(21.7)^{8}$} & $11 / 26(42.3)^{\prime \prime}$ & 21/72 (29.2) \\
\hline \multicolumn{2}{|c|}{ Children with helminths } & \multicolumn{2}{|c|}{$0 / 11(0.0)$} & \multicolumn{2}{|c|}{ 1/3 (33.3) } & $1 / 14(7.1)$ & \multicolumn{2}{|c|}{$2 / 11(18.2)^{\S}$} & $0 / 3(0.0)$ & 2/14 (14.3) \\
\hline \multicolumn{2}{|c|}{ Non-parasitized children } & \multicolumn{2}{|c|}{$12 / 207(5.8)^{\dagger}$} & \multicolumn{2}{|c|}{$10 / 142(7.0)^{\ddagger}$} & $22 / 349(6.3)$ & \multicolumn{2}{|c|}{$31 / 207(15)^{\S}$} & $32 / 142(22.5)^{\| \prime}$ & $63 / 349(18.1)$ \\
\hline \multicolumn{11}{|c|}{$\begin{array}{l}{ }^{*} \text { Values in bold indicate anti-Giardia IgG and IgA positivity in the Giardia-infected group, with significant differences compared with that in the other groups } \\
\left({ }^{P}<<0.001 ; \text { ANOVA). }\right.\end{array}$} \\
\hline \multicolumn{11}{|c|}{$\begin{array}{l}\text { Table 4. Comparison of IgG- and IgA-ELISA positivity rate with the diagnosis of G. duodenalis in feces } \\
\text { ELISA positivity for anti-G. duodenalis antibodies }\end{array}$} \\
\hline & & \multicolumn{4}{|c|}{$\lg G(\mathrm{~N})$} & \multirow{2}{*}{$\begin{array}{l}\text { Kappa index } \\
(95 \% \mathrm{Cl})\end{array}$} & \multicolumn{3}{|c|}{$\lg A(N)$} & \multirow{2}{*}{$\begin{array}{l}\text { Kappa index } \\
(95 \% \mathrm{Cl})\end{array}$} \\
\hline & & Positive & $\mathrm{Neg}$ & & Total & & Positive & Negative & Total & \\
\hline \multirow{3}{*}{$\begin{array}{l}\text { G. duodenalis } \\
\text { in feces }\end{array}$} & Positive & 31 & & & 39 & \multirow[t]{3}{*}{$0.543(0.422-0.664)$} & 28 & 11 & 39 & $0.283(0.162-0.404)$ \\
\hline & Negative & 35 & 40 & & 435 & & 84 & 351 & 435 & \\
\hline & Total & 66 & 40 & & 474 & & 112 & 362 & 474 & \\
\hline
\end{tabular}

Abbreviation: $\mathrm{Cl}$, confidence interval.

Table 5. Giardia duodenalis IgG- and IgA-ELISA positivity rate in sera of children infected with other parasites

\begin{tabular}{lccc}
\hline Enteroparasites & $\begin{array}{c}\text { Parasitological } \\
\text { examination } \\
\text { positivity rate } \\
\text { (N, \%) }\end{array}$ & $\begin{array}{c}\text { Giardia duodenalis ELISA } \\
\text { positivity rate }(\mathrm{N}, \%)\end{array}$ \\
\cline { 3 - 4 } Protozoa & $70(81.4)$ & $10(14.3)$ & $18(25.7)$ \\
Endolimax nana & $31(36.0)$ & $6(19.3)$ & $9(29.0)$ \\
Entamoeba coli & $16(18.6)$ & $3(18.8)$ & $6(37.5)$ \\
Iodamoeba butschilli & $2(2.3)$ & $0(0.0)$ & $0(0.0)$ \\
E. coli + E. nana & $11(12.8)$ & $0(0.0)$ & $1(9.1)$ \\
E. nana + I. butschilli & $2(2.3)$ & $0(0.0)$ & $1(50.0)$ \\
E. nana + E. coli + I. butschilli & $1(1.2)$ & $1(100.0)$ & $1(100.0)$ \\
Blastocystis hominis & $5(5.8)$ & $0(0.0)$ & $0(0.0)$ \\
B. hominis + E. nana & $2(2.3)$ & $0(0.0)$ & $0(0.0)$ \\
Helminths & $16(18.6)$ & $0(0.0)$ & $3(18.8)$ \\
Trichuris trichiura & $4(4.6)$ & $0(0.0)$ & $1(25.0)$ \\
Ascaris lumbricoides & $6(7.0)$ & $0(0.0)$ & $1 .(0.0)$ \\
A. Iumbricoides + T. trichiura & $1(1.2)$ & $0(0.0)$ & $1(100.0)$ \\
E. coli + T. trichiura & $2(2.3)$ & $0(0.0)$ & $1(50.0)$ \\
Enterobius vermicularis & $2(2.3)$ & $0(0.0)$ & $0(0.0)$ \\
Strongyloides stercoralis & $1(1.2)$ & $0(0,0)$ & $0(0.0)$ \\
TOTAL & $86(100.0)$ & $10(11.6)$ & $21(24.4)$ \\
\hline & & & \\
\hline
\end{tabular}

parasites, 10 (11.6\%) and 21 (24.4\%) showed reactivity to specific IgG and IgA, respectively. Giardia antibodies were more frequent in those infected by $E$. nana and E. coli among all parasite infections (Table 5).

\section{DISCUSSION}

In this study, we found a positivity rate of $27.9 \%$ for one or more intestinal parasites in children from Salvador, Bahia. This corroborates with other studies undertaken in Brazil that reported frequencies varying between $5 \%$ and $50 \%[25,26]$. G. duodenalis infection is more common in the infant population than in adults, with especially high frequencies detected in daycare centers and schools [27]. The frequency of G. duodenalis in children from Salvador, Brazil, was reported to range from 13\% to $18.4 \%[11,28]$. Although we observed a lower frequency of G. duodenalis infection in our study, it was the most common pathogenic parasite found, with no differences observed between children in daycare centers and those attending the clinical laboratory. The considerable frequency of $G$. duodenalis and other protozoa observed in this study may be explained, in part, by the small size of the cysts, which facilitates their passage 
through filters and enables their escape from the standard processes of water treatment, in addition to the poor hygiene habits and immune defense immaturity of children [29].

Experimental, clinical, and epidemiological observations indicate that $G$. duodenalis stimulates an immune response in the host [30, 31], and anti-Giardia antibodies have been detected in individuals with $G$. duodenalis infection $[15,16]$. Based on these findings, serological tests were developed to detect specific lgG, IgM, and IgA in the serum of patients. According to Garcia [32], the detection of these antibodies in the serum is not yet suitable for the diagnosis of current $G$. duodenalis infection; however, it can serve as an important tool for epidemiological surveys to determine the extent of $G$. duodenalis exposure of a population.

In our study, the ELISA for anti-G. duodenalis IgG and IgA showed a sensitivity of $80 \%$ and a specificity of $90 \%$ and $83.3 \%$, respectively. Previous studies have found sensitivities ranging from $64-97 \%$ and specificities from $84-85 \%$ in anti-Giardia IgG ELISA $[12,16]$. These differences are possibly due to the different populations studied, stage of infection, or technical variations in the immunoassays. Our standardized in-house ELISA demonstrated a seroprevalence of anti-Giardia IgG and IgA of 13.9\% $(\mathrm{N}=66)$ and $23.6 \%(\mathrm{~N}=112)$, respectively. The detection rate of both antibodies was slightly higher in children from daycare centers (IgG: 16\%; IgA: 28.9\%) than in those tested at the clinical laboratory (IgG: 12.5\%; IgA: 20.2\%), which may reflect higher exposure to the parasite in the former group.

High rates of anti-Giardia IgG have been reported in Mexico, where anti-Giardia IgG was found in $77 \%$ of the sera of lactating women [33] and in 55.3\% of the general population [12]. Guimarães and Sogayar [34] found an anti-Giardia IgG seroprevalence of $63.3 \%$ in children at daycare centers of São Paulo, Brazil. Other studies have shown a reduction in the prevalence of $G$. duodenalis and other enteroparasitoses infections in developing countries due to improvements in hygienic-sanitary and educational conditions in these regions [27, 35], thus reducing exposure to these pathogens. This may explain the lower anti-Giardia IgG seroprevalence in our study.

Studies have suggested that anti-Giardia IgA antibody is a better indicator of current infection than IgG, since it is predominantly produced in the gastrointestinal tract $[15,16]$. However, the seroprevalence of IgA in our study was higher than that of IgG (23.6\% vs. $13.9 \%)$. Overall, $26.7 \%$ of the children did not show $G$. duodenalis in feces, but were positive for specific IgA in serum, which is higher than IgG (12.8\%). Moreover, when we compared the detection of anti-Giardia IgG or IgA in the serum with the detection of cysts and/or of Giardia antigens in feces, the kappa index agreement was moderate for IgG and weak for $\operatorname{lgA}$. This finding suggests that like IgG, IgA is not always associated with current infection. In fact, in endemic areas where exposure to $G$. duodenalis infection is frequent and early, the levels of both serum specific IgG and IgA remain high in adulthood, reflecting recurrent exposure to the parasite $[18,36]$. Experimental studies have also shown that IgA antibodies remain elevated for a long period even after elimination of the parasite [37], corroborating the present results.

Cross-reactivity is a common problem in the detection of antibodies against parasitic antigens, especially in endemic areas. However, few studies have described the cross-reactivity in immunoassays for the detection of anti-Giardia antibodies. We found that $11.6 \%(10 / 86)$ and $24.4 \%(21 / 86)$ of the children infected by other enteroparasites showed reactivity for anti-Giardia IgG and IgA, respectively, which were mostly cases of infection with $E$. nana or $E$. coli. This antibody cross-reactivity may indicate the antigenic similarity between protozoa species, undiagnosed Giardia infection due to a low discharge of cysts or fecal antigens, and/or previous exposure to $G$. duodenalis (immunological memory). Therefore, one limitation of our study was the use of G. duodenalis crude antigens for the in-house ELISA, which may have produced false-positive results due to cross-reactions with other intestinal protozoa. These can occur either because of the high sensitivity of the assay or proximity of protozoan epitopes. Moreover, G. duodenalis and intestinal amoebae are usually co-endemic in several regions of Brazil. Thus, recombinant antigens would be advantageous in terms of greater specificity in comparison with crude preparations, although there is a consensus of the need for a mixture of recombinant antigens to improve sensitivity [38]. More studies are needed to explain these cross-reactions, including the absorption of sera with $E$. nana and $E$. coli antigens before testing in antibody assays.

In conclusion, the parasitological examination and high detection rate of anti-G. duodenalis IgG and IgA observed in this study suggest the high endemicity and early exposure to this protozoan in the children. It is advisable that clinicians should carefully interpret the results of antibody tests as alternative tools for parasite diagnosis, given that IgG and IgA may persist for long periods after parasite clearance, especially in patients from enteroparasite-endemic countries.

\section{ACKNOWLEDGEMENTS}

This work was supported by scholarships for graduate and postgraduate students by the Fundação de Amparo À Pesquisa do 
Estado da Bahia (FAPESB) and Universidade Federal da Bahia (UFBA), Brazil.

\section{AUTHOR CONTRIBUTIONS}

MCAT and NMS conceived and designed the study. MAG produced the Giardia antigens. FTFP, SSC, and SAS performed the ELISAs for detection of anti-Giardia antibodies in sera. GMTC, MCS, and JGSS performed the parasitological examination and coproantigen test for Giardia diagnosis. HCRJr, TCMR, and APM were responsible for recruitment of children and sample collection for the study. MCAT and FTFP carried out the data analysis and wrote the manuscript. MAG, NMS, HCRJr, TCMR, and APM reviewed and commented on the manuscript. All authors revised and approved the final version of the manuscript.

\section{CONFLICTS OF INTEREST}

None declared.

\section{RESEARCH FUNDING}

None declared.

\section{ORCID}

Flávia Thamiris Figueiredo Pacheco https://orcid.org/0000-0001-9718-5651

Silvia Souza de Carvalho https://orcid.org/0000-0002-6636-0063

Samara Alves Santos https://orcid.org/0000-0002-8213-6945

Gisele Maria Trindade das Chagas https://orcid.org/0000-0002-8413-9389

Mariana Conceição Santos https://orcid.org/0000-0002-9119-6090

Jéssica Gleide Souza Santos https://orcid.org/0000-0001-7245-4149

Hugo Costa-Ribeiro Júnior https://orcid.org/0000-0002-9700-4598

Tereza Cristina Medrado Ribeiro https://orcid.org/0000-0003-3329-1142

Ângela Peixoto de Mattos https://orcid.org/0000-0001-8133-7024

Maria Aparecida Gomes https://orcid.org/0000-0003-2556-8068
Neci Matos Soares

https://orcid.org/0000-0003-1409-9884

Márcia Cristina Aquino Teixeira

https://orcid.org/0000-0003-0477-5092

\section{REFERENCES}

1. Sarkari B, Hosseini G, Motazedian MH, Fararouei M, Moshfe A. Prevalence and risk factors of intestinal protozoan infections: a populationbased study in rural areas of Boyer-Ahmad district, Southwestern Iran. BMC Infect Dis 2016;16:703.

2. LaBeaud AD, Nayakwadi Singer M, McKibben M, Mungai P, Muchir EM, McKibben E, et al. Parasitism in children aged three years and under: relationship between infection and growth in rural Coastal Kenya. PLoS Negl Trop Dis 2015;9:e0003721.

3. Ryan U, Hijjawi N, Feng Y, Xiao L. Giardia: an under-reported foodborne parasite. Int J Parasitol 2019;49:1-11.

4. Savioli L, Smith H, Thompson A. Giardia and Cryptosporidium join the "Neglected Diseases Initiative". Trends Parasitol 2006;22:203-8.

5. Minetti C, Chalmers RM, Beeching NJ, Probert C, Lamden K. Giardiasis. BMJ 2016;355:i5369.

6. Robertson LJ, Hanevik K, Escobedo AA, Mørch K, Langeland N. Giardiasis-why do the symptoms sometimes never stop? Trends Parasitol 2010;26:75-82.

7. Koehler AV, Jex AR, Haydon SR, Stevens MA, Gasser RB. Giardia/giardiasis-a perspective on diagnostic and analytical tools. Biotechnol Adv 2014;32:280-9.

8. Van den Bossche D, Cnops L, Verschueren J, Van Esbroeck M. Comparison of four rapid diagnostic tests, ELISA, microscopy and PCR for the detection of Giardia lamblia, Cryptosporidium spp. and Entamoeba histolytica in feces. J Microbiol Methods 2015;110:78-84.

9. Sadaka HA, Gaafar MR, Mady RF, Hezema NN. Evaluation of ImmunoCard Stat test and ELISA versus light microscopy in diagnosis of giardiasis and cryptosporidiosis. Parasitol Res 2015;114:2853-63.

10. Soares R and Tasca T. Giardiasis: an update review on sensitivity and specificity of methods for laboratorial diagnosis. J Microbiol Methods 2016;129:98-102.

11. Silva RK, Pacheco FT, Martins AS, Menezes JF, Costa-Ribeiro H Jr, Ribeiro TC, et al. Performance of microscopy and ELISA for diagnosing Giardia duodenalis infection in different pediatric groups. Parasitol Int 2016;65:635-40

12. Cedillo-Rivera R, Leal YA, Yépez-Mulia L, Gómez-Delgado A, OrtegaPierres G,Tapia-Conyer R, et al. Seroepidemiology of giardiasis in Mexico. Am J Trop Med Hyg 2009;80:6-10.

13. Guo F, Forde MS, Werre SR, Krecek RC, Zhu G. Seroprevalence of five parasitic pathogens in pregnant women in ten Caribbean countries. Parasitol Res 2017;116:347-58.

14. Birkhead G, Janoff EN, Vogt RL, Smith PD. Elevated levels of immunoglobulin A to Giardia lamblia during a waterborne outbreak of gastroenteritis. J Clin Microbiol 1989;27:1707-10.

15. Rodríguez OL, Hagel I, González Y, Roque ME, Vásquez N, López E, et al. Secretory IgA antibody responses in Venezuelan children infected with Giardia duodenalis. J Trop Pediatr 2004;50:68-72.

16. El-Gebaly NS, Halawa EF, Moussa HM, Rabia I, Abu-Zekry M. Saliva and sera IgA and IgG in Egyptian Giardia-infected children. Parasito Res 2012;111:571-5.

17. Goka AK, Rolston DD, Mathan VI, Farthing MJ. Diagnosis of giardiasis 
by specific IgM antibody enzyme-linked immunosorbent assay. Lancet 1986;2:184-6.

18. Goka AKJ, Rolston DDK, Mathan VI, Farthing MJC. Serum anti-Giardia IgA in human Giardia lamblia infection. Serodiagn Immunother Infect Dis 1989;3:273-7.

19. Pacheco FT, Silva RK, Martins AS, Oliveira RR, Alcântara-Neves NM, Silva MP, et al. Differences in the detection of Cryptosporidium and Isospora (Cystoisospora) oocysts according to the fecal concentration or staining method used in a clinical laboratory. J Parasitol 2013;99:1002-8.

20. Faust EC, Sawitz W, Tobie J, Odom V, Peres C, Lincicome DR. Comparative efficiency of various technics for the diagnosis of protozoa and helminths in feces. J Parasitol 1939;25:241-62.

21. Henriksen SA and Pohlenz JF. Staining of cryptosporidia by a modified Ziehl-Neelsen technique. Acta Vet Scand 1981;22:594-6.

22. Keister DB. Axenic culture of Giardia lamblia in TYI-S-33 medium supplemented with bile. Trans R Soc Trop Med Hyg 1983;77:487-8.

23. Lowry OH, Rosebrough NJ, Farr AL, Randall RJ. Protein measurement with the Folin phenol reagent. J Biol Chem 1951;193:265-75.

24. Landis JR and Koch GG. The measurement of observer agreement for categorical data. Biometrics 1977;33:159-74.

25. Fonseca REPD, Barbosa MCR, Ferreira BR. High prevalence of enteroparasites in children from Ribeirão Preto, São Paulo, Brazil. Rev Bras Enferm 2017; 70:566-71.

26. Castro ED, Germini MC, Mascarenhas JD, Gabbay YB, de Lima IC, Lobo Pdos S, et al. Enteropathogens detected in a daycare center, Southeastern Brazil: bacteria, virus, and parasite research. Rev Inst Med Trop Sao Paulo 2015;57:27-32.

27. Pedraza DF, Queiroz Dd, Sales MC. Doenças infecciosas em crianças pré-escolares brasileiras assistidas em creches. Ciênc Saúde Coletiva 2014;19:511-28.

28. Lander RL, Lander AG, Houghton L, Williams SM, Costa-Ribeiro H, Barreto $\mathrm{DL}$, et al. Factors influencing growth and intestinal parasitic infec- tions in preschoolers attending philanthropic daycare centers in Salvador, Northeast Region of Brazil. Cad Saúde Pública 2012;28:2177-88.

29. Santos CK, Grama DF, Limongi JE, Costa FC, Couto TR, Soares RM, et al. Epidemiological, parasitological and molecular aspects of Giardia duodenalis infection in children attending public daycare centers in southeastern Brazil. Trans R Soc Trop Med Hyg 2012;106:473-9.

30. Lopez-Romero G, Quintero J, Astiazarán-García H, Velazquez C. Host defences against Giardia lamblia. Parasite Immunol 2015;37:394-406.

31. Solaymani-Mohammadi S and Singer SM. Giardia duodenalis: the double-edged sword of immune responses in giardiasis. Exp Parasitol 2010; 126:292-7.

32. Garcia LS, ed. Diagnostic medical parasitology. 5th ed. Washington, DC: ASM Press, 2007:576-7.

33. Miotti PG, Gilman RH, Pickering LK, Ruiz-Palacios G, Park HS, Yolken $\mathrm{RH}$. Prevalence of serum and milk antibodies to Giardia lamblia in different populations of lactating women. J Infect Dis 1985;152:1025-31.

34. Guimarães S and Sogayar MI. Detection of anti-Giardia lamblia serum antibody among children of day care centers. Rev Saúde Pública 2002; 36:63-8.

35. Kırkoyun Uysal H, Akgül O, Purisa S, Oner YA. Twenty-five years of intestinal parasite prevalence in Istanbul University, İstanbul Faculty of Medicine: a retrospective study. Turk Parazitolojii Derg 2014;38:97-101.

36. Janoff EN, Taylor DN, Echeverria P, Glode MP, Blaser MJ. Serum antibodies to Giardia lamblia by age in populations in Colorado and Thailand. West J Med 1990;152:253-6.

37. Jiménez JC, Fontaine J, Creusy C, Fleurisse L, Grzych JM, Capron M, et al. Antibody and cytokine responses to Giardia excretory/secretory proteins in Giardia intestinalis-infected BALB/c mice. Parasitol Res 2014; 113:2709-18.

38. Ricciardi A, Ndao M. Diagnosis of parasitic infections: what's going on? J Biomol Screen 2015;20:6-21. 